\title{
STUDI PERFORMANSI ECONOMIZER JENIS ALIRAN SILANG UNTUK PROSES DEGREASING DI PT. X PLANT KARAWANG
}

\author{
Komarudin', Reza Rahmaputra ${ }^{2}$ \\ ${ }^{1,2}$ Program Studi Teknik Mesin S1, Fakultas Teknologi Industri, Institut Sains dan Teknologi Nasional, Jakarta \\ email : komarudin.mt@gmail.com
}

\begin{abstract}
Economizer is Heat Exchanger with Crossflow type that have function as reheater the water to degreasing process. System of Economizer had operated continuously for 7 years. So from this condition Effectiveness and Temperature possibility Can't achieve the Requirement. Degreasing Process is a part of Painting process in Vehicle manufacturing that have function to degrease the oil, dust and etc. A decrease in the effectiveness of this, we need recalculation and compare with design condition to get better effectiveness. Analysis will be refer to fluid flow, overall heat transfer coefficient (U), and Efffectiveness of Economizer it self. Based on result of Calculation and Experiment, the flow of fluid is turbulent flow with Reynold number 12002.14 (Max Condition). Overall heat transfer coefficient $(U)$ is $16.18 \mathrm{~W} / \mathrm{mK}$, while the design condition is $48 \mathrm{~W} / \mathrm{m} . \mathrm{K}$ also for Effectiveness is $32.16 \%$ and the design condition is $50 \%$. This calculation Proved decreasing of that the performance of economizer. It is caused by scaling of the inner pipe with ratio $2.26 \%$. Scaling will be reduce thermal conductivity of the pipe and also gradient of Temperature.
\end{abstract}

Keywords: Economizer, Degreasing Process, Turbulent, Efffectiveness, overall heat transfer Coefficient (U), Scaling, gradient of Temperature.

\section{PENDAHULUAN}

Penggunaan bahan bakar sangat mendominasi pembiayaan produksi di proses Manufacturing. Penggunaan energi untuk proses produksi di PT.X Plant Karawang mencakup bagian yang terbesar dari total biaya produksi. Peralatan utilitas yang ada di proses manufacturing pada umumnya berumur 7 tahunan semenjak pendirian pabrik di Karawang. Efektivitas peralatan utilitas menurun sejalan dengan bertambahnya umur peralatan tersebut.

Salah satu proses produksi di PT. X Plant Karawang adalah Proses Oven di Painting Shop. Diketahui pula bahwa temperatur gas buang yang dihasilkan dari

Chimney Oven masih tinggi antara 200-300 ${ }^{\circ} \mathrm{C}$. Temperatur gas buang yang masih tinggi ini dapat dimanfaatkan kembali untuk memanaskan air yang akan masuk ke dalam proses degrerasing.

Dengan memanfaatkan kembali gas buang tentunya akan dapat menurunkan konsumsi bahan bakar. Salah satu pilihan dalam memanfaatkan panas dari Chimney oven ini adalah dengan pemasangan Economizer. Economizer digunakan sebagai penukar panas untuk mengurangi biaya operasi atau mengekonomiskan biaya untuk bahan bakar dengan memanfaatkan kembali gas buang sisa dari pembakaran.

Sistem kerja Economizer yang dioperasikan secara terus menerus selama 7 tahun tentunya akan mengurangi efektivitas dan temperatur yang dibutuhkan untuk proses degreasing. Oleh karena itu perlu dilakukan evaluasi dan perhitungan ulang untuk mempertahankan kinerja alat penukar panas pada nilai efisiensi yang diharapkan.

Studi kasus yang dilakukan terfokus pada nilai efektivitas Economizer. Adanya kemungkinan penurunan nilai efektivitas Economizer untuk proses degreasing, salah satunya disebabkan oleh temperatur yang dibutuhkan untuk proses degreasing sering tidak mencapai spesifikasi temperatur yang sudah ditentukan. Untuk itu dengan Menghitung dan mengetahui Efektivitas dari Economizer aktual, tujuan akhir dari penelitian ini adalah Memberikan rekomendasi untuk mengoptimalkan kinerja Economizer berdasarkan perhitungan efektivitas Economizer yang sudah dilakukan. 


\section{TINJAUAN PUSTAKA}

Perpindahan panas dapat didefinisikan sebagai suatu proses berpindahnya suatu energi (panas) dari satu zat ke zat lain akibat adanya perbedaan suhu pada daerah tersebut (Muhammad Awwaluddin, 2007) . Ada tiga bentuk mekanisme perpindahan panas yang diketahui, yaitu konduksi, konveksi, dan radiasi.

\section{Konduksi}

Konduksi merupakan perpindahan panas dari tempat yang bertemperatur tinggi ke tempat yang bertemperatur rendah di dalam medium yang bersinggungan langsung. Jika pada suatu benda terdapat gradien suhu, maka akan terjadi perpindahan panas serta energi dari bagian yang bersuhu tinggi ke bagian yang bersuhu rendah, sehingga dapat dikatakan bahwa energi akan berpindah secara konduksi, laju perpindahan kalornya dinyatakan sebagai berikut :

$$
\boldsymbol{q}=-k \cdot A \cdot \frac{\partial T}{\partial x}
$$

Dimana :

$\mathrm{q}$ = laju perpindahan kalor $(\mathrm{W})$

$\partial \mathrm{T} / \partial \mathrm{x}=$ gradien suhu perpindahan kalor

$\mathrm{k}=$ konduktifitas thermal bahan (W/m.K)

$\mathrm{A}=$ luas bidang perpindahan kalor $(\mathrm{m} 2)$

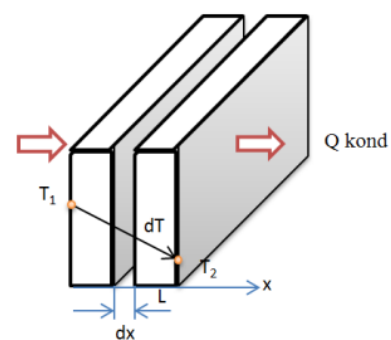

Gambar 1 Laju aliran kalor pada dinding datar

Dari gambar diatas, jika persamaan diintegrasikan sesuai kondisi batas dimana laju aliran merambat pada titik 1 ke titik 2 karena $\mathrm{T} 1$ > T2 Maka persamaan menjadi : q. L = k A (T1T2), dengan demikian besar laju aliran kalor total pada dinding tersebut :

$$
\mathbf{q}=\frac{k \cdot A\left(T_{1}-T_{2}\right)}{L}
$$

Dimana :

q konduksi $=$ Laju perpindahan kalor $(\mathrm{W})$

$\mathrm{L}=$ Tebal dinding $(\mathrm{m})$

$\mathrm{A}=$ Luas bidang perpindahan kalor

$\mathrm{K}=$ konduktifitas termal bahan $(\mathrm{W} / \mathrm{m} . \mathrm{K})$

\section{Radiasi}

Radiasi yaitu pertukaran panas antara dua atau lebih pada permukaan tanpa media perantara yaitu yang dipancarkan oleh gelombang elektromagnetik dimana dipancarkan oleh suatu benda karena adanya suhu dan rambatan secepat cahaya.

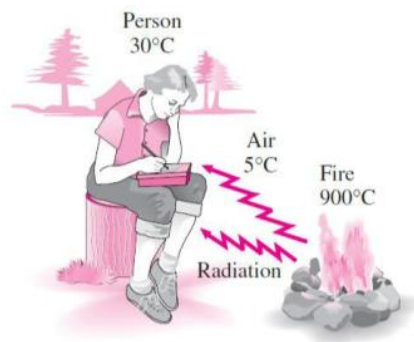

\section{Gambar 2 Perpindahan panas secara radiasi}

Mekanisme perpindahan panas secara radiasi merupakan perubahan energi dalam zat yang permukaannya mempunyai suhu lebih tinggi menjadi energi dalam bentuk gelombang

$$
\mathbf{c}=\lambda . \mathbf{v}
$$

Dimana :

$$
\begin{aligned}
& \mathrm{c}=\text { kecepatan cahaya } \\
& \lambda=\text { panjang gelombang }(\llbracket 10 \rrbracket \wedge(-8) \mathrm{cm}) \\
& \mathrm{v}=\text { frekuensi }
\end{aligned}
$$

\section{Konveksi}

Menurut Incopera dan Hewitt (1981) Perpindahan kalor secara konveksi adalah proses transport energi dengan kerja gabungan dari konduksi kalor, penyimpanan energi dan gerakan mencampur.

Konveksi sangat penting sebagai mekanisme perpindahan energi antara permukaan benda padat dan cair atau gas. Perpindahan kalor secara konveksi dari suatu permukaan yang suhunya di atas suhu fluida disekitarnya berlangsung dalam beberapa tahap. Pertama, kalor akan mengalir dengan cara konduksi dari permukaan ke partikel-partikel fluida yang berbatasan.

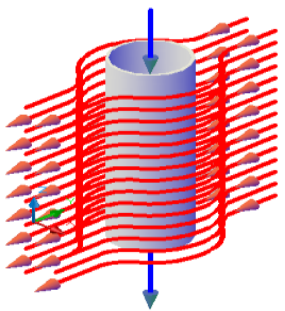

\section{Gambar 3 Perpindahan kalor secara konveksi}

Energi yang berpindah dengan cara demikian akan menaikkan suhu dan energi dalam partikel- 
partikel fluida tersebut. Kedua, partikel-partikel tersebut akan bergerak ke daerah suhu yang lebih rendah dimana partikel tersebut akan bercampur dengan partikel-partikel fluida lainnya.

Laju perpindahan kalor antara suatu permukaan pipa dan suatu fluida dapat dihitung dengan hubungan:

$$
\mathrm{qc}=\text { hc. A. } \Delta \mathrm{T}
$$

Keterangan:

$\mathrm{Qc}=$ Laju perpindahan kalor secara konveksi (W)

$\mathrm{Hc}=$ Koefisien perp. kalor konveksi (W/m2.K)

$\mathrm{A}=$ Luas perpindahan kalor $\left(\mathrm{m}^{2}\right)$

$\Delta \mathrm{T}=$ Beda suhu permukaan $\mathrm{Tw}$ dan fluida $\mathrm{T} \sim$

\section{Persamaan untuk menghitung Efektivitas \\ Economizer \\ Bilangan Reynold}

Bilangan Reynold adalah bilangan yang menunjukan bentuk suatu aliran dalam ruang tertutup (pipa) ataupun terbuka.

$$
\operatorname{Re}=\rho d v / \mu
$$

Keterangan:

$$
\begin{aligned}
\operatorname{Re} & =\text { Bilangan Reynold } \\
\rho & =\text { Massa jenis }(\mathrm{kg} / \mathrm{m} 3) \\
\mathrm{V} & =\operatorname{Kecepatan} \text { aliran fluida }(\mathrm{m} / \mathrm{s}) \\
\mathrm{d} & =\text { Diameter Pipa }(\mathrm{m}) \\
\mu & =\text { Viskositas dinamik }(\mathrm{N} \mathrm{s} / \mathrm{m} 2)
\end{aligned}
$$

\section{Bilangan Nusselt}

Bilangan Nusselt merupakan rasio perpindahan panas konveksi dengan konduksi normal (Wikipedia, 2011). Untuk mendapatkan nilai bilangan Nusselt dapat menggunakan persamaan sebagai berikut:

$$
\text { Nud }=\frac{\text { hd }}{\mathbf{k}}
$$

\section{Keterangan:}

Nud = Bilangan Nusselt

$\mathrm{h}=$ Koefisien konveksi (W/m2 0C)

$\mathrm{d}=$ Diameter pipa $(\mathrm{m})$

$\mathrm{k}=$ Koefisien konduksi (W/m2 0C)

Untuk aliran fluida dalam tabung dengan bilangan Reynolds turbulen, maka untuk mencari bilangan Nusselt Number dapat menggunakan persamaan berikut.

\section{Nud = 0,023 Red0,8Prn}

Pada persamaan di atas terdapat bilangan eksponen $\mathrm{n}$, yang syaratnya sebagai berikut :

$\mathrm{n}=0,4$ fluida mengalami pemanasan $\mathrm{n}=0,3$ fluida mengalami pendinginan
Economizer di PT.X Plant Karawang memiliki pipa tube berjumlah 10 baris $(\mathrm{NL}<10)$, sehingga fluida udara yang melintasi banyak pipa tube dapat menggunakan persamaan berikut untuk mencari nilai bilangan Nusselt.

$$
\text { Nud }=\mathrm{C}_{2} \mathrm{C} \mathrm{Re}^{\mathrm{m}}{ }_{\text {max }} \operatorname{Pr}^{0,36}\left(\operatorname{Pr} / \operatorname{Pr}_{\mathrm{s}}\right)^{1 / 4}
$$

\section{Keterangan :}

Nud = Bilangan Nusselt

$\mathrm{d}=$ Diameter pipa $(\mathrm{m})$

Re, $\max =$ Bilangan Reynolds

$\operatorname{Pr} \quad=$ Bilangan Prandtl

Prs =Bilangan Prandtl suhu permukaan pipa

$\mathrm{C} 2=$ Koreksi Faktor

$\mathrm{C}$ dan $\mathrm{m} \quad=$ Konstanta

Untuk membedakan aliran sejajar (Aligned) dan aliran Silang (Staggered) bisa dilihat gambar 4 dibawah ini :

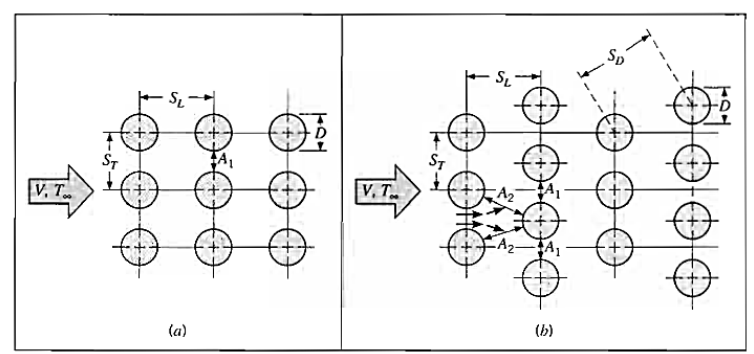

Gambar 4 Aliran Sejajar (a) dan Aliran Silang (b)

\section{Koefisien Perpindahan Panas Total}

Koefisien perpindahan panas total didefinisikan sebagai koefisien hambatan termal total menuju perpindahan panas diantara dua fluida.

Berikut adalah persamaan untuk mencari koefisien perpindahan panas total.

$$
\mathrm{U}_{\mathrm{tot}}=\frac{1}{\frac{1}{h_{i}}+\frac{A o \operatorname{Ln}\left({ }^{\circ} / / r i\right)}{2 \pi k L}+\frac{A i}{A o \cdot h_{o}}}
$$

Keterangan:

$\mathrm{U}=$ Koef. Perpindahan panas total $\left(\mathrm{W} / \mathrm{m}^{2} \mathrm{~K}\right)$

$\mathrm{h}_{\mathrm{i}}=$ Koef. konveksi pada dalam pipa $\left(\mathrm{W} / \mathrm{m}^{2} \mathrm{~K}\right)$

$\mathrm{h}_{\mathrm{o}}=$ Koef. konveksi di luar pipa $\left(\mathrm{W} / \mathrm{m}^{2} \mathrm{~K}\right)$

$\mathrm{L}=$ Panjang pipa $(\mathrm{m})$

$\mathrm{r}_{\mathrm{i}}=$ Jari jari bagian dalam pipa $(\mathrm{m})$

$\mathrm{r}_{\mathrm{o}}=$ Jari jari bagian luar pipa (m)

$\mathrm{k}=$ konduktifitas termal dinding tube $\left({ }^{W} /{ }_{m K}\right)$

\section{Catatan :}

Nilai $h i$ dan ho didapat dari rumus mencari bilangan Nusselt. 
Laju Kapasitas Perpindahan Panas

Untuk menghitung kapasitas perpindahan panas (Cf), dapat dihitung dengan persamaan di bawah ini.

$$
\mathrm{C}_{\mathrm{f}}=\mathrm{m}_{\mathrm{f}} \cdot \mathbf{C p}_{\mathrm{f}}
$$

Keterangan :

$\mathrm{C}_{\mathrm{f}} \quad=$ Kapasitas Perpan Fluida $(\mathrm{W} / \mathrm{K})$

$m_{f} \quad=$ Laju Massa Alir Fluida $(\mathrm{kg} / \mathrm{s})$

$\mathrm{Cp}_{\mathrm{f}} \quad=$ Kalor Spesifik Fluida $(\mathrm{kJ} / \mathrm{kg} \mathrm{K})$

\section{NTU (Jumlah Satuan Perpindahan Panas)}

Nilai NTU ini memberikan petunjuk mengenai ukuran penukar kalor. Untuk mencarinya dapat menggunakan persamaan sebagai berikut (Holman, Edisi 10):

$$
\mathbf{N T U}=\frac{U_{i} A_{i}}{C_{\min }}
$$

Keterangan :

$\mathrm{U}_{\mathrm{i}} \quad=$ Koef. Perp. Panas Total $\left(\mathrm{W} / \mathrm{m}^{2} \mathrm{~K}\right)$

$\mathrm{A}_{\mathrm{i}} \quad=$ Luas Perpindahan Panas $\left(\mathrm{m}^{2}\right)$

$\mathrm{C}_{\text {min }}=$ Laju Kapasitas Perpindahan Panas Minimal $(\mathrm{W} / \mathrm{K})$

\section{Nilai Efektivitas}

Efektivitas adalah nilai yang menunjukan seberapa besar/baik suatu penukar kalor untuk menyerap panas. Efektivitas penukar kalor (heat exchanger effectiveness) untuk crossflow dirumuskan sebagai berikut (Holman, Edisi 10):

$$
\begin{aligned}
& \quad \mathbf{c}=\mathbf{1}-\exp \frac{\left[\exp \left(-\mathrm{NTU} \mathrm{C}_{\mathrm{r}} \mathbf{n}\right)-1\right]}{\mathrm{C}_{\mathrm{r}} \mathbf{n}} \\
& \text { dengan } \mathrm{n}=\mathrm{NTU}^{-0,22}
\end{aligned}
$$

Keterangan :

NTU = Jumlah Satuan Perpindahan Panas

A $\quad=$ Luas perpindahan panas $\left(\mathrm{m}^{2}\right)$

$\mathrm{Cr} \quad=$ Rasio antara $\mathrm{C}_{\max }$ Dan $\mathrm{C}_{\min }$

$\mathrm{C}_{\max } \quad=$ Laju Kapasitas Perpindahan Panas

Maksimal (W/K)

$\mathrm{C}_{\min }=$ Laju Kapasitas Perpindahan Panas

Minimal $(\mathrm{W} / \mathrm{K})$

\section{Diagram Sistem Proses Painting}

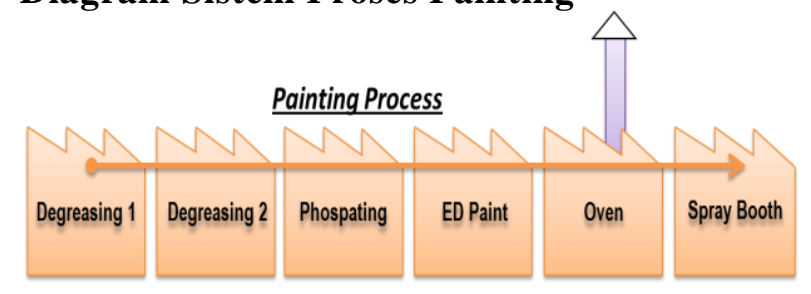

Gambar 5 Painting Process PT. X Plant

Karawang

Degreasing Line merupakan proses untuk menghilangkan minyak atau oli dan kotoran pada body mobil. Sehingga senyawa C (karbon) dapat berikatan dengan $\mathrm{Na}$ (natrium) membentuk $\mathrm{NaC}$ dan $\mathrm{H} 2 \mathrm{O} 2$ sehingga minyak dapat dengan mudah untuk dilarutkan. (Toyota Equipment Standard, 2016).

\section{METODE \\ PENELITIAN \\ PENGOLAHAN DATA \\ Metode Penelitian}

DAN

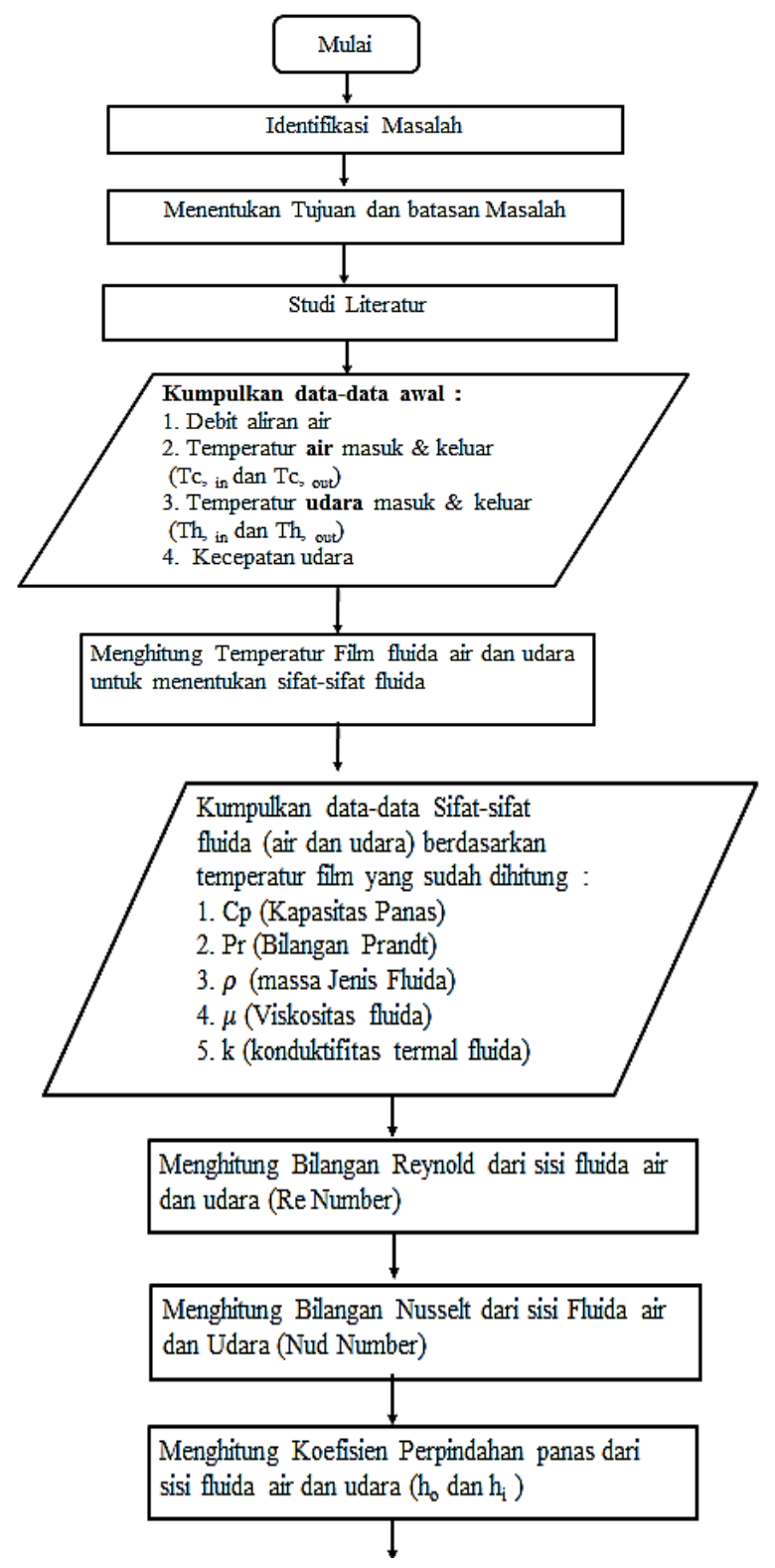




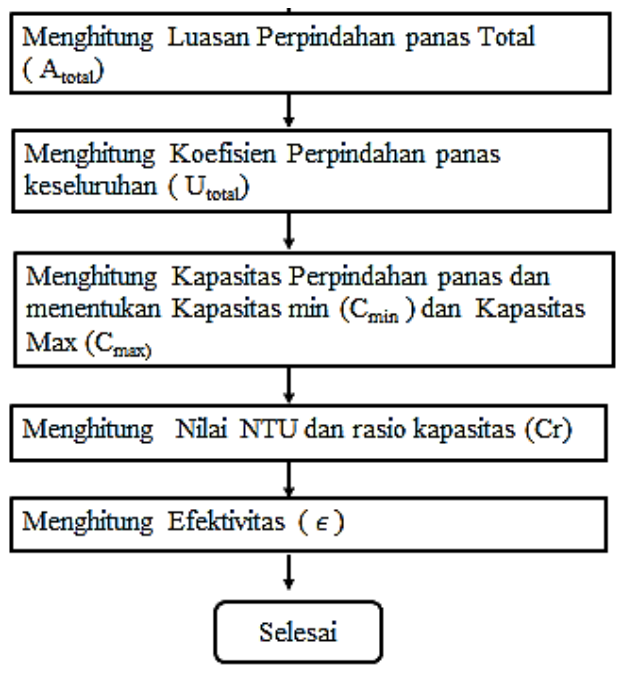

\section{Prosedur Pengambilan data}

\section{Waktu Pengambilan Data}

Data pengukuran Economizer Proses Dergeasing diambil di PT. X Plant Karawang pada tanggal 20 Januari 2017 dan diukur dari mulai pukul $13.00 \mathrm{~s} / \mathrm{d} \quad 17.00$ WIB Perhitungan dan pembahasan menggunakan contoh data pada Pukul 15.00

\section{Parameter Pengujian Economizer Proses Degreasing}

Parameter-parameter riil yang diambil pada saat pengujian Economizer proses Degreasing yaitu:

1. Temperatur air masuk $\left({ }^{\circ} \mathrm{C}\right)$

2. Temperatur air keluar $\left({ }^{\circ} \mathrm{C}\right)$

3. Temperatur Udara masuk $\left({ }^{\circ} \mathrm{C}\right)$

4. Temperatur Udara keluar $\left({ }^{\circ} \mathrm{C}\right)$

5. Debit air dari Pompa $\left(\mathrm{m}^{3} / \mathrm{s}\right)$

6. Kecepatan udara Chimney Oven $(\mathrm{m} / \mathrm{s})$

\section{Langkah Pengambilan/Pengujian data}

Pengujian dilaksanakan Pada tanggal 20 Januari 2017 Pada pukul 13.00 s/d 17.00 WIB dengan selang waktu pengambilan data 1 jam. Langkah langkah yang dilakuan pada pengujian Economizer proses Degreasing ini adalah :

- Mempersiapkan alat ukur yang akan digunakan, alat ukur yang digunakan adalah Anemometer Hot Wire TES-1340 untuk mengukur kecepatan udara di Chimney oven serta Termokopel tipe $K$ di tube dan Shell

- Pengukuran temperatur masuk dan keluar fluida air dan udara pada Economizer proses Degreasing (Gambar 6)

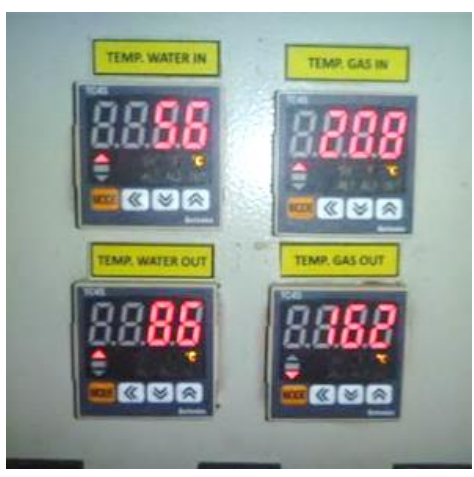

Gambar 6 Panel Indikator Temperatur air dan udara

- Mencatat debit dari air pendingin pada flow meter magnetic

- Mencatat kecepatan udara oven dengan Anemometer Hot Wire TES-1340

- Dan seterusnya s/d pukul 17.00 WIB

\section{Data Spesifikasi Economizer}

1. Skematik Economizer

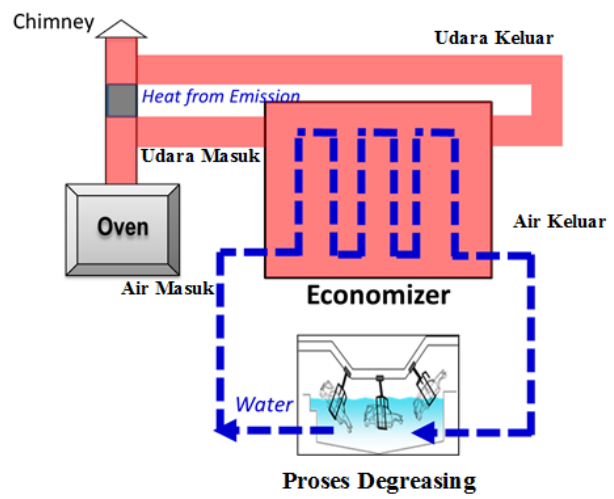

Gambar 7 Skematik Economizer

Economizer ini secara skematik memiliki peranan yang penting dalam proses pemanasan yang terjadi di Proses degreasing karena suhu yang harus dijaga di proses degreasing ini sekitar $80-85^{\circ} \mathbf{C}$, dimana apabila suhu air aktual yang masuk lebih dari range suhu yang sudah ditentukan maka kualitas proses degreasing akan berdampak ke proses selanjutnya yaitu phospating process

\section{Spesifikasi Data Economizer}

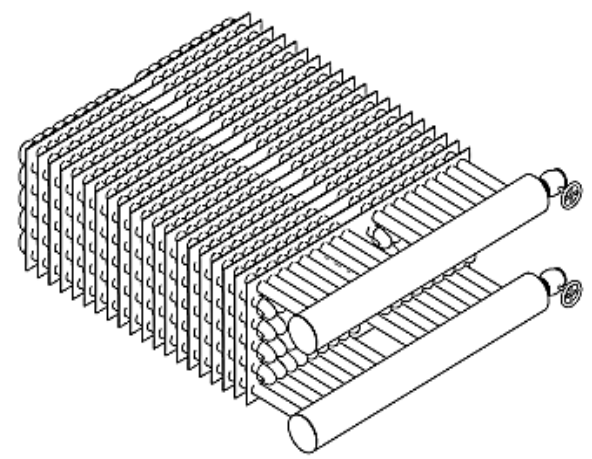

Gambar 8 Economizer tube side view 
- $\quad$ Tipe $=$ Fins and Tube

- $\quad$ Design Code= ASME Code Sec VIII Div 1

- $\quad$ TEMA Class $=\mathrm{C}-$ General Service

- Material Standard= ASME

- $\quad$ Aliran Fluida= Aliran Menyilang (Cross Flow)

- Bahan Material Pipa = SA-106 K03006 Grd B Smls. Pipe

- Bahan Material Fins = Carbon Steel

- Bahan Material Header= SA-106 K03006 Grd B Smls. Pipe

- $\mathrm{Q}_{\text {air }}=0,028 \mathrm{~m}^{3} / \mathrm{s}$

- Diameter dalam pipa Air $\left(\mathrm{D}_{\mathrm{i}}\right)=0,039 \mathrm{~m}$

- Jarak Antar Pipa (Sn)=44,9 mm = 0,0449 m

- Jarak Antar pipa $(\mathrm{Sp})=52,5 \mathrm{~mm}=0,0525 \mathrm{~m}$

- Jumlah tube $=180$

- Diameter dalam Pipa Udara $\left(\mathrm{D}_{\mathrm{o}}\right)=0,042 \mathrm{~m}$

- Panjang Pipa air $\left(\mathrm{L}_{\mathrm{i}}\right)=1,8 \mathrm{~m}$

- Efektivitas Perancangan $=50 \%$

- Overall heat Coefficeient $=48 \mathrm{~W} / \mathrm{m} . \mathrm{K}$

\section{Perhitungan Efektivitas Economizer}

Waktu Pengambilan data :

Januari 2017 Pukul 15.00 WIB

Diketahui:

- Perhitungan data sisi air (Tube)

$$
\begin{aligned}
& \mathrm{T}_{\text {masuk }}=53^{\circ} \mathrm{C} \\
& \mathrm{T}_{\text {keluar }}=76^{\circ} \mathrm{C}
\end{aligned}
$$

- Mencari Temperatur film fluida $\left(\mathrm{T}_{\mathrm{f}}\right)$

$$
\begin{aligned}
\mathrm{T}_{\mathrm{f}} & =\frac{\text { Tmasuk }+ \text { Theluar }}{2} \\
& =\frac{(53+76) o_{\mathrm{C}}}{2} \\
& =64,5{ }^{\circ} \mathrm{C}=273+64,5=337,5 \mathrm{~K}
\end{aligned}
$$

- Mencari sifat - sifat fisik fluida

Sifat - sifat fisik fluida air didapatkan dengan metode interpolasi (Holman, Edisi 10) ${ }^{1}$

$$
\begin{array}{ll}
\rho_{\text {air }} & =980.69 \mathrm{~kg} / \mathrm{m}^{3} \\
\mathrm{C}_{\text {air }} & =4.18 \mathrm{~kJ} / \mathrm{kg} . \mathrm{K} \\
\mu_{\text {air }} & =4.3 \times 10^{-4} \mathrm{~N} \mathrm{~s} / \mathrm{m}^{2} \\
\mathrm{k}_{\text {air }} & =0,659 \mathrm{~W} / \mathrm{m} . \mathrm{K} \\
\operatorname{Pr}_{\text {air }} & =2.75
\end{array}
$$

- Menghitung Luas Penampang Tube $\left(\mathrm{m}^{2}\right)$

$$
\begin{aligned}
& \mathrm{A}_{\mathrm{i}}=\frac{\pi}{4} D i^{2} \times 180 \\
& \mathrm{~A}_{\mathrm{i}}=\frac{\pi}{4}(0,039 \mathrm{~m})^{2} \times 180 \\
& \mathrm{~A}_{\mathrm{i}}=0,21 \mathrm{~m}^{2}
\end{aligned}
$$

- Menghitung kecepatan air (m/s)

$$
\begin{array}{ll}
v_{\text {air }} & =\frac{\text { Qair }}{A} \\
v_{\text {air }} & =\frac{Q \text { air }}{A i}
\end{array}
$$

$$
v_{\text {air }} \quad=\frac{0,028 \mathrm{~m}^{3} / \mathrm{s}}{0,21 \mathrm{~m}^{2}}=0,13 \mathrm{~m} / \mathrm{s}
$$

- Menghitung bilangan Reynold

$\operatorname{Re}=\frac{\rho \text { di Vair }}{\mu}$

$\operatorname{Re}=\frac{980,69 \mathrm{~kg}_{\mathrm{m}^{\mathrm{s}}} 0,039 \mathrm{~m} 0,13^{\mathrm{m} / \mathrm{s}}}{4,3 \times 10^{-4} \mathrm{~kg} / \mathrm{ms}}$

$\mathrm{Re}=11563,019($ Aliran turbulen $\mathrm{Re}>4000)$

- Menentukan bilangan Nusselt sisi air

Nud $\quad=0,023 \operatorname{Red}_{\text {air }}{ }^{0,8} \operatorname{Pr}_{\text {air }}{ }^{0,4}$

(mengalami pemanasan)

Nud $=0,023 \cdot(11563,019)^{0,8} \cdot(2,75)^{0,4}$

Nud $=61,33$

- Mencari Koefisien Perpindahan Panas Sisi Air (h air)

$$
\begin{aligned}
& \operatorname{Nud}_{\text {air }}=\frac{h_{\text {air }} \cdot d_{\text {tube }}}{k_{\text {air }}} \\
& \mathrm{h}_{\text {air }} \quad=\frac{\text { Nud }_{\text {air }} \cdot k_{\text {air }}}{d_{\text {tube }}} \\
& \mathrm{h}_{\text {air }} \quad=\frac{61,33 \cdot 0,659}{0,039}\left[\frac{W / m \cdot K}{m}\right] \\
& \mathrm{h}_{\text {air }}=981,85 \mathrm{~W} / \mathrm{m}^{2} \mathrm{~K}
\end{aligned}
$$

\section{- Perhitungan data sisi Udara $\left(\mathrm{CO}_{2}\right)$}

$$
\begin{aligned}
& \mathrm{T}_{\text {masuk }}=208^{\circ} \mathrm{C} \\
& \mathrm{T}_{\text {keluar }}=162^{\circ} \mathrm{C}
\end{aligned}
$$

- Mencari temperatur film fluida udara

$$
\begin{aligned}
\mathrm{T}_{\text {f udara }}= & \frac{T_{u i}+T_{u o}}{2} \\
& =\frac{(208+162)^{\circ} \mathrm{C}}{2} \\
& =185^{\circ} \mathrm{C}=458 \mathrm{~K}
\end{aligned}
$$

- Mencari temperatur permukaan pipa tube

$$
\begin{aligned}
& \mathrm{T}_{\text {wtube }}=\mathrm{T}_{\mathrm{f} \text { air }}+\Delta \mathrm{T} \\
& \Delta \mathrm{T}=\frac{\frac{1}{h_{\text {air }}}}{\frac{1}{h_{\text {air }}}+\frac{A_{i}}{A_{0}}} \times\left(\mathrm{T}_{\mathrm{f} \text { udara }}-\mathrm{T}_{\mathrm{f} \text { air }}\right)
\end{aligned}
$$

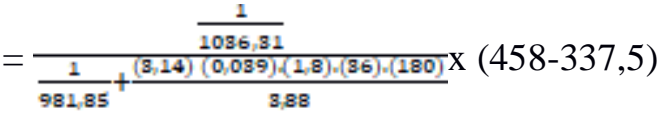

$$
\begin{aligned}
& =\frac{0,1162}{6,810}=0.017 \mathrm{~K} \\
& \mathrm{~T}_{\mathrm{w} \text { tube }}=\mathrm{T}_{\mathrm{f} \text { air }}+\Delta \mathrm{T} \\
& =337,5+0,017 \\
& =337,517 \mathrm{~K}
\end{aligned}
$$


Konduktifitas termal bahan pipa Carbon Steel didapatkan di Tabel 5.3 (Holman, Edisi 10)² Nilai konduktifitas termal bahan pipa Carbon Steel Pada suhu dinding $337,517 \mathrm{~K}$ adalah $\mathbf{3 4} \mathrm{W} / \mathrm{m} \mathrm{K}$

- Mencari sifat termodinamika udara

Untuk mencari sifat termodinamika udara, penulis menggunakan tabel 5.6 buku Heat Transfer Holman, Edisi ke-10

$$
\begin{array}{ll}
\rho_{\text {udara }} & =1,173 \mathrm{~kg} / \mathrm{m}^{3} \\
\mathrm{C}_{\text {udara }} & =0,985 \mathrm{~kJ} / \mathrm{kg} \cdot{ }^{0} \mathrm{C} \\
\mu_{\text {udara }} & =220 \times 10^{-7} \mathrm{~N} \mathrm{~s} / \mathrm{m}^{2} \\
\mathrm{k}_{\text {udara }} & =0,0296 \mathrm{~W} / \mathrm{m} \cdot{ }^{0} \mathrm{C} \\
\operatorname{Pr}_{\text {udara }} & =0,717 \\
\left.\operatorname{Pr}_{\text {pipa }}\right) & =0,758 \\
\mathrm{~V}_{\text {udara }} & =0,639 \mathrm{~m} / \mathrm{s}
\end{array}
$$

- Menghitung kecepatan maksimal udara

$$
\mathrm{V}_{\text {udara max }} \quad=\mathrm{v}_{\text {udara }} \times \frac{S_{T}}{\left(S_{T}-d\right)}
$$

- Menghitung Nilai Reynolds Udara

$$
\begin{aligned}
\operatorname{Red}_{\text {udara }} & =\frac{\rho_{\text {udara }} \cdot v_{\text {maxudara }} \cdot d_{\text {tube }}}{\mu_{\text {udara }}} \\
& =\frac{1,173 \cdot 0,66 \cdot 0,039}{220 \times 10^{-7}}\left[\frac{\mathrm{kg} / m^{\mathrm{s} \cdot} \cdot m_{s} \cdot m}{N^{s} / m^{2}}\right] \\
& =1372,41
\end{aligned}
$$

- Mencari konstanta $\mathrm{C}$ dan $\mathrm{m}$

$$
\begin{aligned}
\frac{S_{T}}{S_{L}} & =\frac{1,15 m}{1,33 m} \\
& =0,86<2
\end{aligned}
$$

Mencari nilai $\mathrm{C}$ dan $\mathrm{m}$ dibutuhkan data bilangan Reynolds dan $\mathrm{S}_{\mathrm{T}} / \mathrm{S}_{\mathrm{L}}$. Lalu dari tabel 3.2 Konstanta tube bank pada aliran crossflow didapat konstanta $\mathrm{C}$ dan $\mathrm{m}$ sebagai berikut (Incropera, Edisi $6)^{3}$ :

Tabel 3.2 Mencari nilai $\mathrm{C}$ dan $\mathrm{m}$ dalam aliran Crossflow

\begin{tabular}{|c|c|c|c|}
\hline Konfigurasi & $\mathrm{Re}_{, \max }$ & $\mathrm{C}$ & $\mathrm{m}$ \\
\hline Aligned & $10-10^{2}$ & 0,80 & 0,40 \\
\hline Staggered & $10-10^{2}$ & 0,90 & 0,40 \\
\hline $\begin{array}{c}\text { Aligned } \\
\left(\mathrm{S}_{\mathrm{T}} / \mathrm{S}_{\mathrm{L}}>0,7\right)\end{array}$ & $10^{3}-2 \times 10^{5}$ & 0,27 & 0,63 \\
\hline $\begin{array}{c}\text { Staggered } \\
\left(\mathrm{S}_{\mathrm{T}} / \mathrm{S}_{\mathrm{L}}<2\right)\end{array}$ & $10^{3}-2 \times 10^{5}$ & $0,35\left(\mathrm{~S}_{\mathrm{T}} / \mathrm{S}_{\mathrm{L}}<2\right)^{1 / 5}$ & 0,60 \\
\hline
\end{tabular}

Koreksi factor (C2) didapat dari Tabel 3.3 dibawah :

Tabel 3.3 Koreksi Faktor (C2) untuk NL $=10$

\begin{tabular}{lcccccc:c|ccc}
$N_{L}$ & $\mathbf{1}$ & $\mathbf{2}$ & $\mathbf{3}$ & $\mathbf{4}$ & $\mathbf{5}$ & $\mathbf{7}$ & $\mathbf{1 0}$ & $\mathbf{1 3}$ & $\mathbf{1 6}$ \\
\hline Aligned & 0.70 & 0.80 & 0.86 & 0.90 & 0.92 & 0.95 & 0.97 & 0.98 & 0.94 \\
Staggered & 0.64 & 0.76 & 0.84 & 0.89 & 0.92 & 0.95 & 0.97 & 0.98 & 0.94 \\
\hline
\end{tabular}

Dari Tabel 3.2 dan Tabel 3.3 didapat nilai

$$
\begin{array}{rlr}
\mathrm{C} & =0,35(1,15 / 1,33)^{1 / 5} \quad \mathrm{C}_{2}=0.97 \\
& =(0,35)(0,86)^{1 / 5} & \\
& =(0,35 \times 0,97)=\mathbf{0 , 3 3} \\
\mathrm{m} & =\mathbf{0 , 6 0}
\end{array}
$$

- Menghitung Nilai Nusselt Number Udara

$$
\begin{aligned}
\operatorname{Nud}_{\text {udara }} & =C_{2} \cdot C \cdot \operatorname{Red}_{\text {udara }}{ }^{m} \cdot \operatorname{Pr}_{\text {udara }}{ }^{0,36} \cdot\left(\frac{P_{T_{\text {uddara }}}}{\operatorname{Pr}\left(T_{\text {pipa }}\right)}\right)^{1 / 4} \\
& =0,97 \cdot 0,33 \cdot(1372,41)^{0,60} \cdot(0,717)^{0,36} \cdot\left(\frac{0,717}{0,758}\right)^{1 / 4} \\
& =21,63
\end{aligned}
$$

- Menghitung Koefisien Konveksi Udara

$$
\begin{aligned}
\operatorname{Nud}_{\text {udara }} & =\frac{h_{\text {udara }} \cdot d_{\text {tube }}}{k_{\text {udara }}} \\
\text { h udara } & =\frac{\text { Nud } d_{\text {udara }} \cdot k_{\text {udara }}}{d_{\text {tube }}} \\
& =\frac{21,63 \cdot 0,0296}{0,039}\left[\frac{\mathrm{W} / m \cdot K}{m}\right] \\
& =16,41 \mathrm{~W} / \mathrm{m}^{2} . \mathrm{K}
\end{aligned}
$$

- Menghitung Luas Daerah Perpindahan Panas Total

$$
\begin{aligned}
A_{\text {tot }} & =N \cdot \pi \cdot d \cdot L \\
& =(20) \cdot(9) 3,14.0,039 \mathrm{~m} \cdot 1,8 \mathrm{~m} . \\
& =39,67 \mathrm{~m}^{2}
\end{aligned}
$$

- Menghitung Koefisien Perpindahan Panas Total

$$
\begin{aligned}
\mathrm{U}_{\text {tot }} & =\frac{1}{\frac{1}{h_{\text {udara }}}+\frac{A O\left(\mathrm{Ln}^{T O} / \mathrm{ri}\right)}{2 \pi k L}+\frac{A o}{A i \cdot h_{\text {air }}}} \\
& =\frac{1}{\frac{1}{16,41}+\frac{42.72\left(\mathrm{Ln}^{0.042} / 0.039\right)}{23,14341.8}+\frac{42,72}{39,671036,31}} \\
& =16,16 \mathrm{~W} / \mathrm{m}^{2} . \mathrm{K}
\end{aligned}
$$

- Menghitung Kapasitas Perpindahan Panas

$$
\begin{aligned}
\mathrm{C}_{\text {udara }} & =\mathrm{m}_{\text {udara }} \cdot C \mathrm{Cp}_{\text {udara }} \\
& =\left(\rho_{\text {udara }} \mathrm{A}_{\text {cooler }} \mathrm{V}_{\text {udara }}\right) \cdot \mathrm{C} \mathrm{p}_{\text {udara }} \\
& =\left(1,173 \cdot(1,8 \cdot 1,2 \cdot 0,63) \cdot(0,985)\left[\frac{\mathrm{kg}}{\mathrm{m}^{\mathrm{g}}}\right]\left(\mathrm{m}^{2}\right)\left(\frac{\mathrm{m}}{\mathrm{g}}\right)\left(\frac{\mathrm{kJ}}{\mathrm{kg} \cdot \mathrm{K}}\right)\right.
\end{aligned}
$$




\section{$=1,529 \mathrm{~kW} / \mathrm{K} \approx 1529,17 \mathrm{~W} / \mathrm{K}$}

Dari hasil perhitungan di atas dapat disimpulkan bahwa $\mathrm{C}_{\text {air }}$ lebih besar dari $\mathrm{C}_{\text {udara }}$, maka $\mathrm{C}_{\mathrm{air}}=\mathrm{C}_{\max }$, sedangkan $\mathrm{C}_{\mathrm{udara}}=\mathrm{C}_{\min }$.

- Menghitung NTU

$$
\begin{aligned}
\mathrm{NTU} & =\frac{U_{i} A_{i}}{C_{\min }} \\
& =\frac{(16,16)(39,67)}{1529,17}\left[\frac{\left[\frac{W}{m^{2}}\right]\left(m^{2}\right)}{W / K}\right] \\
& =0,42
\end{aligned}
$$

- Menghitung rasio $C_{r}$

$$
\begin{aligned}
\mathrm{C}_{\mathrm{r}} & ={ }^{C_{\min } / C_{\max }} \\
& =1529,17 / 11 \\
& =0,01
\end{aligned}
$$

- Menghitung Efektivitas Economizer

$$
\begin{aligned}
& \epsilon=1-\exp \frac{\left[\exp \left(-N T U C_{r} n\right)-1\right]}{C_{r} n} \\
& n=N^{-0,22} \\
& \epsilon=1-\exp \frac{\left[\exp \left((-0,42)(0,01)(0,42)^{-0,32}\right)-1\right]}{(0,01)(0,42)^{-0,32}} \\
& \epsilon=1-0,657 \\
& \epsilon=0,342 \approx \mathbf{3 4 , 2 2} \%
\end{aligned}
$$

\section{ANALISIS HASIL PERHITUNGAN Deskripsi Analisis}

Proses Analisa yang dilakukan bertujuan untuk mendapatkan nilai unjuk kerja aktual dari Economizer proses Degreaing di PT. X Plant Karawang. Unjuk kerja aktual akan dibandingkan dengan unjuk kerja ketika perancangan (desain) sehingga bisa terlihat apakah performansi Economizer yang digunakan mengalami penurunan atau tidak.

\section{Data Hasil Analisis}

Dari hasil analisa yang didapatkan, pada Economizer proses degreasing di PT. X Plant Karawang ini dimulai dari menghitung Sifat-sifat termodinamika dari kedua fluida (air dan udara), Mencari bilangan Reynold, Menentukan jenis aliran kedua fluida, koefisien perpindahan panas keseluruhan, dan efektivitas perancangan dan pengujian Economizer.

- Bilangan Reynold dan Jenis aliran fluida

Pada sisi fluida air berdasarkan tabel 4.1 Dapat diketahui bahwa aliran air pada saat pengujian aktual sama dengan aliran air pada saat perancangan yaitu merupakan aliran turbulen. Hal ini ditunjukan dari hasil bilangan reynold fluida air baik pengujian maupun Desain lebih besar dari bilangan reynold fluida air (Re>4000). Namun terdapat perbedaan nilai bilangan reynold antara pengujian aktual dan Desain. Dimana, nilai pengujian aktual lebih rendah dari nilai Desainnya.

Tabel 4.1 Perbandingan Bilangan Reynold air (Desain $x$ Pengujian

\begin{tabular}{|c|c|c|c|c|}
\cline { 2 - 5 } \multicolumn{1}{c|}{} & \multicolumn{2}{c|}{ Desain } & \multicolumn{2}{c|}{ Pengujian Aktual } \\
\cline { 2 - 5 } \multicolumn{1}{c|}{} & Min & Maks & Min & Maks \\
\hline Reynold & 149590 & 260006 & 10968.44 & 12002.14 \\
\hline Aliran & \multicolumn{2}{|c|}{$\begin{array}{c}\text { Turbulen } \\
(\text { Re }>4000)\end{array}$} & \multicolumn{2}{c|}{ Turbulen $(\operatorname{Re}>4000)$} \\
\hline$\Delta \mathrm{T}(\mathrm{K})$ & \multicolumn{2}{|c|}{40} & \multicolumn{2}{c|}{23} \\
\hline
\end{tabular}

Nilai Bilangan reynold pada pengujian menjadi lebih rendah dari desainnnya hal ini disebabkan oleh adanya gradient Suhu $(\Delta T)$. Gradien suhu akan mempengaruhi nilai massa jenis fluida dan viskositas fluida. Semakin besar gradient suhunya maka massa jenis $(\rho)$ dan viskositas fluida ( $\mu)$ menjadi lebih rendah sehingga pengaruh terhadap nilai bilangan reynold aktualnya pun akan menjadi lebih rendah.

Nilai bilangan Reynold Untuk fluida udara berdasarkan dari data perhitungan sebesar 1372.57 (Minimum) dan 1468.38 (Maksimum). Dari hasil perhitungan tersebut dapat disimpulkan bahwa jenis aliran udara pada saat pengujian Economizer adalah aliran laminar.

- Koefisien Perpindahan panas Total

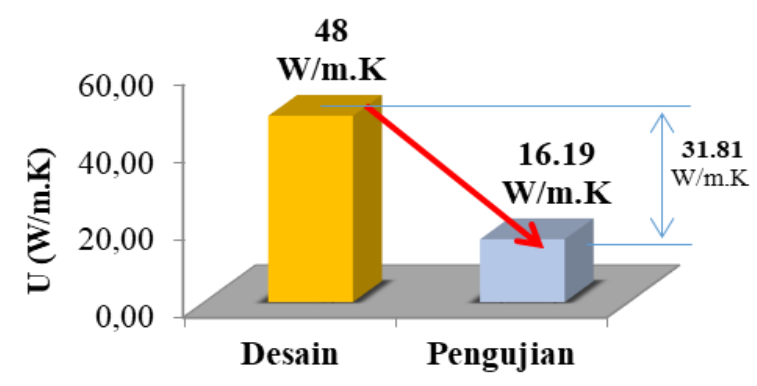

Grafik 4.1 Koef. Perpindahan panas (Desain $x$ Pengujian)

Dari grafik 4.1 diatas dapat diketahui bahwa nilai koefisien perpindahan keseluruhan pada saat pengujian dari Economizer proses degreasing di PT. X Plant Karawang mengalami penurunan secara signifikan yaitu sebesar $\mathbf{3 2} \%$.

Menurunnya nilai koefisien perpindahan panas Economizer proses degreasing di PT. X Plant Karawang salah satu penyebabnya yaitu akibat Economizer sudah beroperasi cukup lama, hal ini memungkinkan dari adanya pengerakan (Scaling) didalam pipa yang menyebabkan nilai konduktifitas termal nya pun menurun. Hal ini mengakibatkan gradient suhu menjadi lebih rendah. 
- Efektivitas Perancangan dan Pengujian Economizer

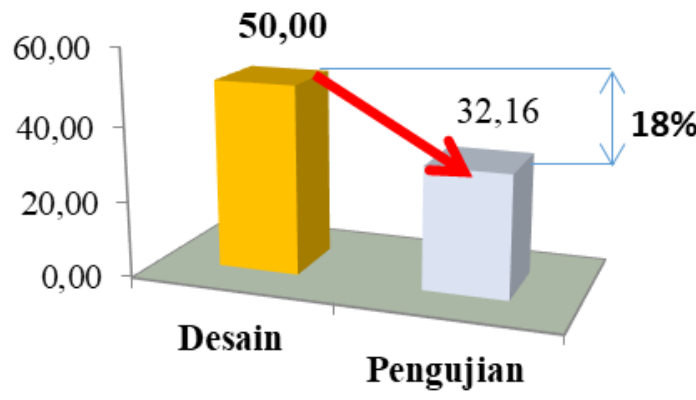

Grafik 4.2 Efektivitas Economizer (Desain x Pengujian)

Menurunnya Efektivitas Economizer proses degreasing di PT. X Plant Karawang sama halnya dengan analisis koefisien perpindahan panas sebelumnya dimana salah satu penyebabnya yaitu akibat Economizer sudah beroperasi cukup lama. Jika melihat grafik $\mathbf{4 . 2}$ Efektivitas actual Economizer jelas mengalami penurunan yang signifikan dari efektivitas Desainnya yaitu Persentase Penurunan sebesar 18\%. Adanya penurunan performansi ini dipengaruhi salah satunya oleh pengerakan (scaling) pada pipa tube air sehingga perpindahan panas dari udara ke air tidak optimal.

Analisis Pengerakan (Scaling)

Untuk dapat mengetahui besarnya persentase pengerakan, dapat dilakukan perhitungan sebagai berikut :

Diketahui :

Tai standar perancangan (Desain) $=303 \mathrm{~K}$

Tao standar perancangan (Desain) $=343 \mathrm{~K}$

Tf air standar perancangan (Desain) $=323 \mathrm{~K}$

Perhitungan untuk mencari bilangan Reynold, Nusselt, dan koefisien konveksi sebagai berikut :

$$
\begin{array}{ll}
\text { pair } & =988,1 \mathrm{~kg} / \mathrm{m} 3 \\
\text { Cpair } & =4,181 \mathrm{~kJ} / \mathrm{kg} . \mathrm{K} \\
\mu \text { air } & =547 \times 10-6 \mathrm{~N} . \mathrm{s} / \mathrm{m} 2 \\
\text { kair } & =0,644 \mathrm{~W} / \mathrm{m} . \mathrm{K} \\
\text { Prair } & =3,55
\end{array}
$$

- Mencari Bilangan Reynolds Air

$$
\begin{aligned}
\operatorname{Red}_{\text {air }}= & \frac{\rho_{\text {air }} \cdot v_{\text {air }} \cdot d_{\text {tube }}}{\mu_{\text {air }}} \\
& =\frac{988,1 \cdot 0,13 \cdot 0,039}{547 \times 10^{-6}}\left[\frac{\mathrm{kg} / \mathrm{m}^{\mathrm{s}} \mathrm{m} / \mathrm{s} \cdot \mathrm{m}}{\mathrm{N}^{\mathrm{s}} / \mathrm{m}^{\mathrm{s}}}\right] \\
& =9158,440
\end{aligned}
$$

- Mencari Bilangan Nusselt Air

$\mathrm{Nud}=0,023 \cdot \operatorname{Red}_{\text {air }}{ }^{0,8} \cdot \operatorname{Pr}_{\text {air }}{ }^{0,4}$

(mengalami pemanasan)

Nud $=0,023 .(9158,440)^{0,8} \cdot(4,181)^{0,4}$

$\mathrm{Nud}=60,21$

- Mencari Nilai Koefisien Konveksi Air

$$
\mathrm{Nud}_{\text {air }}=\frac{h_{\text {air }} \cdot d_{\text {tube }}}{k \text { air }}
$$

$$
\begin{aligned}
\mathrm{h}_{\text {air }} & =\frac{N u d_{\text {air }} \cdot k_{\text {air }}}{d_{\text {tube }}} \\
\mathrm{h}_{\text {air }} & =\frac{60,21 \cdot 0,644}{0,039}\left[\frac{\mathrm{W} / \mathrm{m} \cdot \mathrm{K}}{\mathrm{m}}\right] \\
\mathrm{h}_{\text {air }} & =994,236 \mathrm{~W} / \mathrm{m}^{2} \cdot \mathrm{K}
\end{aligned}
$$

hair $=994,236 \mathrm{~W} / \mathrm{m} 2 . \mathrm{K}$ merupakan koefisien konveksi air sesuai desain awal (bersih dari pengerakan), lalu kita ambil rata-rata koefisien konveksi air dari seluruh data dan didapat hair $=$ $971,71 \mathrm{~W} / \mathrm{m} 2 . \mathrm{K}$ ini merupakan koefisien konveksi air aktual. Maka kita dapat menghitung persentase pengerakan sebagai berikut :

Persentase pengerakan $(\%)$

$=100-\left(h_{-}(\right.$air aktual $) /\left(\mathrm{h}_{-}(\right.$air desain $\left.\left.)\right) \times 100 \%\right)$

$=100-(971.71 /(994.236) \times 100 \%)$

$=2,26 \%$

Persentase 2,26\% ini merupakan rugi dari pengerakan pada Economizer proses Degresing di PT. X Plant Karawang. Jika efektivitas Economizer adalah $32 \%$, dan jika efektivitas desain Economizer adalah 50\%, maka $15.74 \%$ adalah rugi-rugi lainnya.

\section{KESIMPULAN}

Dari hasil pengamatan dan Analisis yang dilakukan pada tanggal 20 Januari 2017 mengenai Performansi Economizer pada proses degreasing yang digunakan pada sistem pemanasan ulang (reheater) di PT. X Plant Karawang, didapatkan beberapa kesimpulan sebagai berikut :

Aliran air pada saat pengujian aktual sama dengan aliran air pada saat desainnya yaitu merupakan aliran turbulen.

Nilai Bilangan reynold pada pengujian menjadi lebih rendah dari desainnnya hal ini disebabkan oleh adanya gradient Suhu $(\Delta T)$. Gradien suhu akan mempengaruhi nilai massa jenis fluida dan viskositas fluida.

Nilai koefisien perpindahan keseluruhan pada saat pengujian dari Economizer proses degreasing di PT. X Plant Karawang mengalami penurunan secara signifikan yaitu presentase penurunan sebesar $32 \%$.

Efektivitas aktual Economizer mengalami penurunan yang signifikan dari efektivitas Desainnya yaitu Persentase Penurunan sebesar $18 \%$.

Adanya penurunan Nilai Koefisien perpindahan panas keseluruhan dan efektivitas disebabkan oleh adanya pengerakan (scaling) pada 
pipa yang mengakibatkan konduktifitas termal menurun.

Adanya rugi-rugi yang disebabkan oleh pengerakan dapat dibuktikan dengan perhitungan presentase pengerakan sebesar $2.26 \%$

\section{DAFTAR PUSTAKA}

Awwaluddin, Muhammad. (2007), Analisis Perpindahan Kalor Pada Heat Exchanger Pipa Ganda dengan Sirip Berbentuk Delta Wing, UNS, Semarang.

Holman, Jack P., Heat Transfer ,Department of Mechanical Engineering Southern Methodist University, Edisi ke-10

Incropera, Frank P. dan David P. Dewitt., (2010), Fundamentals of Heat and Mass Transfer, $10^{\text {th }}$ Ed., John Wiley and Sons, Inc., New York.

Komarudin, (2004), Buku ajar Perpindahan Panas, ISTN Press, Jakarta

Miyagawa, Toyota Safety and Equipment Manual Book Standardization, Toyota Motor Corp., Aichi, Japan, 2016 